\title{
Є.O. Макаров
}

Національний університет цฺивільного захисту України, Україна

\section{ЕЛЕКТРОФЛОТАЦІЙНА ОЧИСТКА СТІЧНИХ ВОД МОЛОКОЗАВОДІВ: ХІМІКО-ТЕХНОЛОГІЧНІ АСПЕКТИ}

Експериментально встановлені хіміко-технологічні закономірності реагентно-електрофлотаційної очистки стічних вод молокозаводів. Показано, щэо найбільший ступінь очищення від етеророзчинних речовин 87-88\% забезпечується додаванням ферум хлориду $\mathrm{FeCl}_{3}$ в концентраиії 150-200мг/дм ${ }^{3}$ при рН середовища

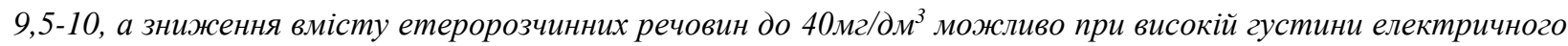
струму та тривалій електрофлотаиії.

Ключові слова: стічні води, молокозавод, етеророзчинні речовини, електрофлотачія, реагент, ступінь очистки.

\section{Постановка проблеми}

Одне 3 перших місць за об'ємом і концентрацією забруднень стічних вод займає молочна галузь, яка складається 3 різних видів підприємств: молокоприймальні пункти, сепараторні відділення, міські молочні заводи, сироробні i маслоробні заводи [1-3]. На підприємствах молочної галузі стічні води складають близько $90 \%$ від використовуваної підприємствами чистої води. При середніх питомих витратах води $5 \mathrm{M}^{3}$ на тону молока, в залежності від потужності підприємства, за добу утворюється близько $500 \mathrm{M}^{3}$ стічних вод.

Стічні води молокопереробних підприємств відносяться до категорії висококонцентрованих вод 3 нестабільним складом. Основними нормативними показниками, якими прийнято характеризувати небезпечність стічних вод є хімічне споживання кисню (ХСК), біохімічне споживання кисню (БСК), загальний вміст етеророзчинних речовин, загальний вміст нітрогену, показник кислотності $\mathrm{pH}$, прозорість. Окрім згаданих показників стічні води технологій переробки молока характеризуються підвищеним вмістом завислих речовин, сульфатівіонів $\mathrm{SO}_{4}{ }^{2-}$, хлорид-іонів $\mathrm{Cl}^{-}$, іонів амонію $\mathrm{NH}_{4}{ }^{+}$, фосфат-іонів $\mathrm{PO}_{4}{ }^{3-}$, іонів кальцію $\mathrm{Ca}^{2+}$, а також сухого та прожареного залишків. Дисперсна фаза стічних вод представлена нерозчинними у воді жирами та частинками коагульованого білка $[4,5]$.

На відміну від механічних та хімічних, електрохімічні методи очищення забезпечують високий ступінь видалення забруднень зі стічних вод молокозаводів. Електрохімічні установки компактні та прості у використанні. Серед електрохімічних методів, що в теперішній час ефективно застосовуються для очищення стічних вод від жирів та білків, необхідно відмітити електрофлотацію та електрокоагуляцію [6-12].

\section{Аналіз останніх досліджень і публікацій}

Серед електрохімічних методів, які в теперішній час використовуються для очищення стічних вод молокозаводів, найбільш ефективними $\epsilon$ електрофлотація, електрокоагуляція та різноманітні схеми, в яких ці методи поєднуються. Але і ці методи характеризуються недосконалістю та мають певні недоліки.

Дослідження [13] показали недостатню ефективність електрофлотаційного видалення суспендованих білків 3 водних розчинів. Показано, що величина $\mathrm{pH}$ розчинів суттєво впливає на стан білкової молекули, що в свою чергу зумовлює ефективність електрофлотаційного видалення. Визначено, що при $\mathrm{pH}=4,5$ та густині току $100 \mathrm{~A} / \mathrm{M}^{2}$ ступінь вилучення досягає $63 \%$ для розчинів 3 концентрацією білку 50мг/дм ${ }^{3}$ та $53 \%$ у випадку концентрації 1000мг/м². В роботах [11, 14-15] установлено, що використання різних методів флотації при локальній очистці стічних вод молочних заводів, дозволяє отримати практично однакові ефекти очистки, які для виробничих умов не перевищують 50-60\% по завислим речовинам i жирам та 20-30\% по ХСК. Авторами [16] встановлено, що регулювання $\mathrm{pH}$, температури, густини току та тривалості електрофлотаційної обробки дозволяє підвищити ступінь очистки стічних вод від жирних кислот до 70-80\%. Показано, що найбільша ефективність вилучення жирних кислот досягається при $\mathrm{pH} \leq 3$, температурі $10-25^{\circ} \mathrm{C}$, тривалості обробки 10-20 хвилин та густині току $330-380 \mathrm{~A} / \mathrm{M}^{2}$ при $0,33-0,44 \kappa В т ч / \mathrm{M}^{3}$. У розробленому [17] процесі пінно-електролітичної сепарації, який дозволяє вилучати жири та білки з концентрованих 
стічних вод, використовуються послідовно методи пневматичної флотації та електрофлотації. Ступінь очистки стічних вод від жирів складає $65-70 \%$, ХСК знижується на 25-30\%. Для підвищення ступеня очистки рекомендується додавання близько $110 \mathrm{Mг} / л$ лігносульфонової кислоти. При цьому ефективність видалення жирів підвищується до 90\%. Інші органічні сполуки практично не видаляються, оскільки ХСК знижується несуттєво (до 35\%).

Для здійснення ефективного процесу електрофлотації важливим є вибір матеріалу електродів, головним чином, анодів. Відомо, що промислові окисно-рутенієві електроди використовуються для очистки стічних вод з високим вмістом хлорид-іонів. При інших умовах ці електроди швидко руйнуються. Окисно-свинцеві електроди 3 покриттям на основі титану коштовні і дефіцитні. Поширені в електрофлотаційних процесах графітові аноди схильні до інтенсивного зношення в області високої густини току, що характерно для електрофлотації [18]. Вищевказане свідчить, що використання методу електрофлотації як у якості самостійного методу, так і в якості допоміжного при комбінованих способах очищення, малоефективне. У випадку реагентноелектрофлотаційних схем очищення використання електрофлотації ускладняється пасивацією електродів, наприклад, при застосуванні солей кальцію. Тому деякі автори $[19,20]$ вважають, що електрофлотацію доцільно використовувати у якості окремого екологічно безпечного методу для доочистки слабко забруднених стічних вод.
В роботах $[17,21]$ була встановлена ефективність послідовного використання методів електрокоагуляції та електрофлотації. При густині току в камері електрокоагуляції 20-30A/M м $^{2}$ в камері електрофлотації - 140A/м ${ }^{2}$ та тривалості обробки 9 хвилин ефект очистки стічних вод від жирів становив 93-96\%, від завислих речовин - 85-90\%. Значення ХСК знизилось на 62-65\%. Осад, що утворюється в процесі очищення, рекомендується зневоднювати та використовувати на корм худобі або у якості добрив.

\section{Постановка завдання}

Отже, на основі аналізу літературних джерел можна стверджувати, що технологічна та економічна ефективність електрохімічних методів, а, саме, електрофлотаціійної очистки, в значній мірі залежить від хімічного складу, температури і кислотності стічної води, наявності попередньої реагентної обробки та хіміко-технологічних параметрів електрохімічної обробки. Тому встановлення хіміко-технологічних особливостей процесу електрофлотаційної очистки стічних вод молокозаводів $€$ важливою науково-практичною задачею.

\section{Виклад основного матеріалу}

Для дослідження обрано стічні води молокопереробного підприємства Сумської області.

Характеристика стічних вод молокозаводу наведена у табл. 1.

Таблиця 1.

Характеристика стічних вод молокозаводу

\begin{tabular}{|l|c|}
\hline \multicolumn{1}{|c|}{ Показник } & Кількісне значення показника \\
\hline Водневий показник $\mathrm{pH}$ & 5,75 \\
\hline Хімічне споживання кисню, мгО/дм & 3500 \\
\hline Прозорість, см & 1,6 \\
\hline Етеророзчинних речовин, мг/дм ${ }^{3}$ & 392 \\
\hline Завислих речовин, мг/дм ${ }^{3}$ & 865 \\
\hline Нітроген амонію, мг/дм & 11,5 \\
\hline Нітроген загальний, мг/дм $^{3}$ & 72,75 \\
\hline Залишок після випарювання, мг/дм ${ }^{3}$ & 2860 \\
\hline Залишок після прожарювання, $\mathrm{мг/дм}$ & 1176 \\
\hline
\end{tabular}

Для реагентної обробки стічних вод обраний ферум хлорид $\mathrm{FeCl}_{3}$ у вигляді $5 \%$ водного розчину. Для прискорення гідролізу реагенту в якості лужної добавки використовувався кальцій оксид (вапно) $\mathrm{CaO}$ в сухому вигляді та натрій гідроксид $\mathrm{NaOH}$ у вигляді $5 \%$ водного розчину. Для прискорення утворення осаду (шламу) використовувався флокулянт неіонний поліакриламід (ПАА) у вигляді $0,05 \%$ водного розчину.

Ефективність обробки досліджувалась за наступними показниками стічної води: водневий показник $\mathrm{pH}$, прозорість та кількість етеророзчинних речовин.

Визначення водневого показника $\mathrm{pH}$ проводилось при кімнатній температурі $\left(18-20^{\circ} \mathrm{C}\right)$ за допомогою портативного рН-метра марки SX 711 (Китай) з точністю вимірювання $\pm 0,01 \mathrm{pH}$.

Прозорість води визначалась $з$ використанням приладу Снеллена, який представляє собою скляний циліндр $з$ пласким дном [22]. Починаючи від дона, циліндр градуйований по висоті у сантиметрах. Висота градуйованої частини становила $30 \mathrm{~cm}$. У 
нижній частині циліндра $є$ відвідний кінець для зливання води 3 гумовою трубкою. Досліджувана вода перемішувалась i, не фільтруючи, наливалась доверху в циліндр, під дно якого поміщався шрифт №1. Відстань від дона до шрифту повинна була становити 4cм. За необхідності, вода 3 циліндра поступово виливалась доти, доки букви шрифту не будуть добре видимі. Висота стовпа води, виражена в сантиметрах, вказувала на ступінь прозорості води. Визначення проводилось у добре освітленому приміщенні на відстані не більше 1м від вікна.

Визначення кількості етерозчинних речовин (жирів та мінеральних олій) здійснювалось методом багатократної екстракції петролейним етером в якості екстрагента [22]. Після випарювання етеру 3 екстракту, ваговим методом визначалась кількість речовин, що розчинилась у етері. Вміст етерозчинних речовин (ЕРР), мг/дм³ ${ }^{3}$ розраховувався за формулою: $\mathrm{EPP}=\left(\mathrm{m}_{1}-\mathrm{m}_{2}\right) \cdot \mathrm{V}_{2} \cdot 1000 / \mathrm{V}_{1} \cdot \mathrm{V}$, де $-\mathrm{m}_{1}-$ маса бюксу із залишком після видалення екстрагента, мг; $\mathrm{m}_{2}$ - маса пустого бюксу, мг; V - об'єм води, взятий для досліду, $\mathrm{cm}^{3} ; \mathrm{V}_{2}-$ об'єм колби з екстрактом, см $^{3}$; $\mathrm{V}_{1}$ - об'єм аліквотної порції екстракту, $\mathrm{cm}^{3}$.
Стічні води молокозаводу після додавання реагентів (ферум хлориду та лужної добавки) перемішувались протягом 5-10 хвилин, потім додавався флокулянт ПАА в кількості $5 \mathrm{Mг} /$ дм $^{3}$. Кількість доданого ферум хлориду становила 100$200 \mathrm{Mг} /$ дм $^{3}$. Результати реагентної обробки стічної води представлені у таблицях 1, 2. Після перемішування стічні води відстоювались протягом 1 години. При цьому фіксувались швидкість осадження та об’єм утвореного осаду. У фільтраті визначались прозорість та кількість етеророзчинних речовин.

Після додавання ферум хлориду $\mathrm{FeCl}_{3}$ у стічну воду відбувається процес гідролізу катіону $\mathrm{Fe}^{3+} 3$ утворенням малорозчинного гідроксиду та вивільненням протонів:

$$
\mathrm{Fe}^{3+}+3 \mathrm{H}_{2} \mathrm{O} \leftrightarrow \mathrm{Fe}(\mathrm{OH})_{3} \downarrow+3 \mathrm{H}^{+}
$$

Внаслідок гідролізу утворюється малорозчинний ферум гідроксид, який адсорбує на поверхні різні забруднювачі. Частинки гідроксиду з адсорбованими забруднювачами 3 часом укрупнююся та осідають у вигляді осаду (шламу). При цьому водневий показник рН стічних вод знижується.

Таблиця 2.

Характеристика стічних вод після реагентної обробки з використанням натрій гідроксиду

\begin{tabular}{|c|c|c|c|c|c|}
\hline \multirow{2}{*}{$\begin{array}{c}\text { Концентрація } \\
\text { ферум хлориду } \\
\mathrm{FeCl}_{3}, \text { мг/дм }\end{array}$} & \multicolumn{2}{|c|}{ pH стічних вод } & \multirow{2}{*}{$\begin{array}{c}\text { Концентрація } \\
\text { ЕРР, мг/дм }\end{array}$} & \multirow[b]{2}{*}{ Прозорість, см } & \multirow{2}{*}{$\begin{array}{c}\text { Об’єм осаду } \\
\text { (шламу), \% }\end{array}$} \\
\hline & $\begin{array}{c}\text { Після } \\
\text { додавання } \\
\mathrm{FeCl}_{3} \\
\end{array}$ & $\begin{array}{c}\text { Після } \\
\text { додавання } \\
\mathrm{NaOH}\end{array}$ & & & \\
\hline- & - & - & 392 & 1,6 & - \\
\hline 100 & 4,9 & 7,8 & 56 & 6,6 & 15 \\
\hline 100 & 4,9 & 8,6 & 52 & 7,0 & 15 \\
\hline 100 & 4,9 & 9,6 & 52 & 8,3 & 14 \\
\hline 150 & 3,9 & 7,5 & 58 & 7,0 & 15 \\
\hline 150 & 3,9 & 8,6 & 55 & 9,0 & 15 \\
\hline 150 & 3,9 & 9,6 & 50 & 11,0 & 17 \\
\hline 200 & 3,8 & 7,6 & 50 & 9,0 & 17 \\
\hline 200 & 3,8 & 8,6 & 50 & 10,0 & 17 \\
\hline 200 & 3,8 & 9,6 & 49 & 14,0 & 18 \\
\hline
\end{tabular}

Таблиця 3.

Характеристика стічних вод після реагентної обробки з використанням вапна

\begin{tabular}{|c|c|c|c|c|c|}
\hline \multicolumn{2}{|c|}{ Концентрація, мг/дм ${ }^{3}$} & \multirow{2}{*}{$\begin{array}{c}\text { pH стічних вод } \\
\text { після } \\
\text { додавання } \mathrm{CaO}\end{array}$} & \multirow{2}{*}{$\begin{array}{c}\text { Концентрація } \\
\text { ЕРР, мг/дм }\end{array}$} & \multirow[b]{2}{*}{ Прозорість, см } & \multirow[b]{2}{*}{$\begin{array}{l}\text { Об'єм осаду } \\
\text { (шламу), \% }\end{array}$} \\
\hline $\mathrm{FeCl}_{3}$ & $\mathrm{CaO}$ & & & & \\
\hline 100 & 500 & 7,2 & 47 & 10,2 & 10 \\
\hline 100 & 1000 & 10,5 & 33 & 16,0 & 30 \\
\hline
\end{tabular}

Як видно 3 даних таблиці 2, зі збільшенням концентрації ферум хлориду $\mathrm{FeCl}_{3}$ в діапазоні до 100мг/дм ${ }^{3}$ гідроліз відбувається повільно, в діапазоні 100-150мг/дм ${ }^{3}$ спостерігається стрибок рН середови- ща, а в діапазоні концентрацій більше $150 \mathrm{мг} /$ дм $^{3}-$ гідроліз практично не залежить від концентрації солі, тобто не відбувається. Процес вилучення етеророзчинних речовин в значній мірі залежить від $\mathrm{pH}$ 
середовища і зростає при підвищенні лужності стічної води. Найбільший вплив $\mathrm{pH}$ середовища спостерігається при концентрації реагенту 100$150 \mathrm{мг} /$ дм $^{3}$. При додаванні реагенту концентрацією 200мг/дм ${ }^{3}$ ефект очистки несуттєво залежить від $\mathrm{pH}$ середовища. Але саме ця концентрація забезпечує максимальний ефект очистки. Найбільший ступінь очищення від етеророзчинних речовин 87-88\% забезпечується додаванням заліза хлориду в концентрації 150-200мг/дм³ при рН середовища 9,510. Проте, необхідно зазначити, що додавання хімічних реагентів має i негативні аспекти. При додаванні хлоридів або сульфатів металів у стічні води потрапляє велика кількість відповідно хлоридабо сульфат-іонів. Зважаючи на те, що вихідні стічні води молокозаводів зазвичай містять 170-400мг/л хлорид-іонів та 150-160мг/л сульфат-іонів [3], використання солей металів не завжди $є$ виправданим. В такому випадку необхідний пошук та застосування безреагентних фізико-хімічних методів очистки.

При аналізі даних, представлених у табл. 3, встановлено, що при використанні вапна для збільшення рН стічної води в концентрації 500мг/дм³ спостерігається більш ефективне видалення етеророзчинних речовин та завислих речовин (збільшується прозорість) та менша кількість утвореного осаду. Також встановлено, що додавання вапна дозволяє знизити концентрацію ферум хлориду до 100мг/дм³. Об'єм утвореного осаду (шламу) також знижується. Найбільш ефективним $є$ додавання ферум хлориду, а потім вапна. Спочатку при додаванні $\mathrm{FeCl}_{3}$ відбувається коагуляція білків та часткова деемульгування жирової емульсії. Після додавання в воду вапна відбувається гідроліз і утворення ферум гідроксиду $\mathrm{Fe}(\mathrm{OH})_{3}$, на поверхні якого адсорбуються забруднення. Таким чином, за результатами, отриманими в ході попередніх досліджень, були обрані оптимальні концентрації реагентів - $\mathrm{FeCl}_{3}-100 \mathrm{мг} /$ дм $^{3}$ та $\mathrm{CaO}-500$ мг/дм ${ }^{3}$ та $\mathrm{pH}$ стічної води - 7,2. Після перемішування стічної води 3 реагентами, додавався флокулянт ПАА та проводилась обробка в горизонтальному електрофлотаторі, схема якого представлена на рис. 1.

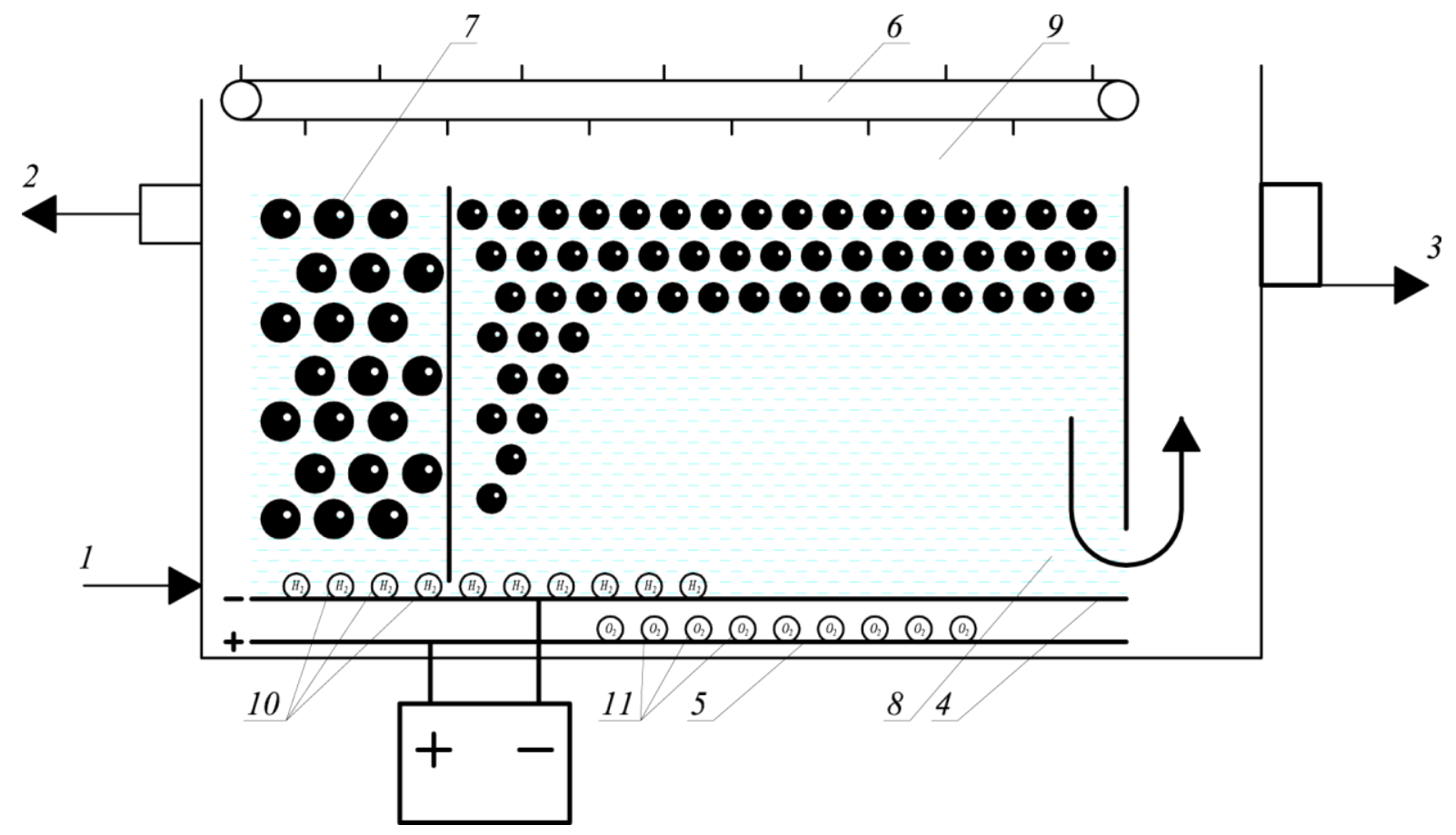

Рис. 1. Схема горизонтального електрофлотатора:

1 - подача стічної води; 2 - збір і випуск флотошламу; 3 - збір і випуск очищеної води; 4 - перфорований катод 3 нержавіючої сталі; 5 - графітовий анод; 6 - механізм для згрібання флотошламу; 7 - флотошлам; 8 очищена вода; 9 - флотокамера; 10 - бульбашки водню; 11 - бульбашки кисню.

В процесі електрофлотаційної очистки підготовленої води варіювались густина електричного струму від 0,01 до $0,05 \mathrm{~A} / \mathrm{cm}^{2}$, висота стовпа стічної води над катодом від 100 до 300мм та тривалість обробки - 5, 10, 20, 30 хвилин. Отримані в результаті проведеного експерименту дані впливу технологічних параметрів електрофлотації на процес очистки стічних вод молокозаводів представлені в табл. 4. 
Таблиця 4.

Вплив технологічних параметрів електрофлотаційної обробки на процес очистки

\begin{tabular}{|c|c|c|c|c|c|}
\hline \multirow[b]{2}{*}{$\begin{array}{l}\text { Висота стовпа } \\
\text { стічної води, мм }\end{array}$} & \multicolumn{3}{|c|}{ Технологічні параметри обробки } & \multirow[b]{2}{*}{$\begin{array}{c}\text { Концентрація } \\
\text { ЕРР, мг/дм }\end{array}$} & \multirow[b]{2}{*}{$\begin{array}{c}\text { Об’єм } \\
\text { флотошламу, } \\
\%\end{array}$} \\
\hline & $\begin{array}{c}\text { Густина } \\
\text { електричного } \\
\text { струму, A/см² }\end{array}$ & $\begin{array}{c}\text { Електрична } \\
\text { напруга, В }\end{array}$ & $\begin{array}{c}\text { Тривалість, } \\
\text { хвилин }\end{array}$ & & \\
\hline- & - & - & - & 392 & - \\
\hline 300 & 0,01 & 9,7 & 10 & 47 & 15 \\
\hline 300 & 0,01 & 9,7 & 20 & 46 & 15 \\
\hline 300 & 0,01 & 9,7 & 30 & 46 & 15 \\
\hline 300 & 0,03 & 15,5 & 10 & 46 & 20 \\
\hline 300 & 0,03 & 15,5 & 20 & 42 & 20 \\
\hline 300 & 0,03 & 15,5 & 30 & 42 & 20 \\
\hline 200 & 0,01 & 10 & 10 & 46 & 15 \\
\hline 200 & 0,01 & 10 & 20 & 44 & 15 \\
\hline 200 & 0,01 & 10 & 30 & 44 & 15 \\
\hline 200 & 0,03 & 16 & 20 & 44 & 22 \\
\hline 200 & 0,03 & 16 & 30 & 44 & 22 \\
\hline 200 & 0,05 & 26 & 20 & 43 & 22 \\
\hline 200 & 0,05 & 26 & 30 & 43 & 22 \\
\hline 100 & 0,05 & 26 & 10 & 42 & 21 \\
\hline 100 & 0,05 & 26 & 20 & 41 & 21 \\
\hline 100 & 0,05 & 26 & 30 & 40 & 21 \\
\hline
\end{tabular}

При аналізі даних табл. 5 встановлено, що використання методу реагентно-електрофлотаційної обробки стічних вод молокозаводів для видалення етеророзчинних та завислих речовин забезпечує необхідний ступінь очистки в області вивчених технологічних параметрів. Але, необхідно відмітити, що зниження вмісту етеророзчинних речовин до

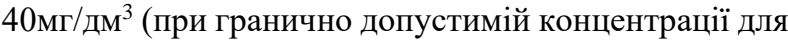
стічних вод молокозаводів 50мг/дм ${ }^{3}$ ) можливо тільки при високій тривалості обробки (20-30 хвилин), густини $\left(0,05 \mathrm{~A} / \mathrm{cm}^{2}\right)$ і напруги (26 В) електричного струму, що призводить до високих витрат електроенергії. Ще одним недоліком є утворення великої кількості флотошламу, який потребує спеціальної обробки, що збільшує експлуатаційні витрати.

\section{Висновки}

Аналізуючи отримані результати досліджень можна зробити наступні висновки. Проведені експериментальні дослідження та встановлені основні хіміко-технологічні закономірності реагентноелектрофлотаційної очистки стічних вод молокозаводів. Встановлено, що процес вилучення етеророзчинних речовин в значній мірі залежить від $\mathrm{pH}$ середовища i зростає при підвищенні лужності стічної води. Найбільший вплив $\mathrm{pH}$ середовища спостерігається при концентрації $\mathrm{FeCl}_{3} \quad 100$ $150 \mathrm{Mr} /$ дм$^{3}$. При додаванні $\mathrm{FeCl}_{3}$ концентрацією $200 \mathrm{Mг} /$ дм $^{3}$ ефект очистки несуттєво залежить від $\mathrm{pH}$ середовища. Найбільший ступінь очищення від етеророзчинних речовин $87-88 \%$ забезпечується додаванням ферум хлориду $\mathrm{FeCl}_{3}$ в концентрації 150-200мг/дм ${ }^{3}$ при рН середовища 9,5-10.

Встановлено, що при використанні вапна для збільшення рН стічної води в концентрації 500мг/дм ${ }^{3}$ спостерігається більш ефективне видалення етеророзчинних речовин та завислих речовин (збільшується прозорість), а також утворюється менша кількість осаду. Узагальнюючи отримані дані, були обрані оптимальні концентрації реагентів для попередньої обробки стічної води $-\mathrm{FeCl}_{3}-100$ мг/дм ${ }^{3}, \mathrm{CaO}-500 \mathrm{мг} /$ дм $^{3}$ та рН стічної води $-7,2$. Встановлено, що використання методу реагентноелектрофлотаційної обробки стічних вод молокозаводів для видалення етеророзчинних та завислих речовин забезпечує необхідний ступінь очистки в області вивчених технологічних параметрів.

Показано, що зниження вмісту етеророзчинних речовин до 40мг/дм ${ }^{3}$ (при гранично допустимій концентрації для стічних вод молокозаводів $50 \mathrm{Mг} /$ дм $^{3}$ ) можливо тільки при високій тривалості обробки (20-30 хвилин), густини $\left(0,05 \mathrm{~A} / \mathrm{cm}^{2}\right)$ i напруги (26 В) електричного струму, що призводить до високих витрат електроенергії.

\section{Література}

1. Саакаш, Г.В. Очистка сточных вод предприятий по переработке молока / Г.В. Саакаш, А.Ф. Колова, Т.Я. Пазенко // Вестник КрасГАУ. - 2016. - №8. - С. 97103.

2. Шевченко, Т.А. Экспериментальное исследование интенсификации проиесса напорной флотации при 
очистке сточных вод молокоперерабатывающего предприятия / Т.А. Шевченко, А.А. Шевченко // Восточноевропейский журнал передовых технологий. - 2015. №1/6(79). - C. 4-12.

3. Andronov, V.A. Research of the regularities of forming and chemical composition of sewage water of a dairy processing company/V.A. Andronov, Ye.O. Makarov, Yu.M. Danchenko, T.M. Obizhenko // Technogenic and ecological safety. -2020. - №1/6(79). - P. 4-12.

\section{4. Макаров, С.O.}

Екологічна

небезпека висококонцентрованих стічних вод молокопереробних підприємств / С.О. Макаров // Сталий розвиток - стан та перспективи: Матеріали II Міжнародного симпозіуму SDEV'2020. Львів, 2020. - C. 235-236.

5. Коневич, М. Особливості стічних вод молокозаводів / M. Коневич, В. Гудь // Матеріали XV наукової конференціі ТНТУ імені Івана Пулюя. Тернопіль, 2011. - С. 309.

6. Gerson de Freitas Silva Valente. The efficiency of electrocoagulation using aluminum electrodes in treating wastewater from a dairy industry / Gerson de Freitas Silva Valente, Regina Celia Santos Mendonca, Jose Antonio Marques Pereira // Ciencia Rural, Santa Maria. - 2015. V.45, №9. P. 1713-1719.

7. Chezeau, B. Treatment of dairy wastewater by electrocoagulation process: Advantages of combined iron/aluminum electrodes (published online 15.07.2019) / B. Chezeau, L. Boudriche, C. Vial and A. Boudjemaa // Separation Science and Technology. - 2019. - №15.

8. Aitbara, A. Continuous treatment of industrial dairy effluent by electrocoagulation using aluminum electrodes / A. Aitbara, M. Cherifi, S. Hazourli and J.-P. Leclerc // Desalination and Water Treatment. - 2016. - V.57, №8. - P. 3395-3404.

9. Benaissa, F. Optimization and kinetic modeling of electrocoagulation treatment of dairy wastewater / F. Benaissa, H. Kermet-Said and N. Moulai-Mostera // Desalination and Water Treatment. - 2016. - V.57, №13. - P. 5988-5994.

10. Varank, G. Application of Central Composite Design approach for dairy wastewater treatment by electrocoagulation using iron and aluminum electrodes: modeling and optimization / G. Varank, M. E. Sabuncu // Desalination and Water Treatment. - 2015. - V.56, №1. - P. 33-54.

11. Озорнова, А.В. Исследование флотационного процесса очистки сточных вод молочного производства и разработка способа его интенсификации / А.В. Озорнова // Молодежный научно-технический вестник. - 2016. - №11. -C. 20.

12. Терновська, О.I. Очистка промислових стоків підприємств по переробиі тваринницької продукції від жиру / О.І. Терновська, С.Б. Ковтун, А.І. Кукушкін, В.I. Д'яконов, О.В. Чеботарьова, Г.В. Фесенко // Комунальне господарство міст. - 2015. - Вип. 124. - С. 39-42.

13. Бродский, В.А. Электрофлотачионное извлечение суспензий белков из водных растворов / В.А. Бродский, П.Н. Кисиленко, В.А. Колесников, М.Г. Гордиенко // Успехи в химии и химической технологии. - 2016. - Т. ХХХ, №3. - C. 46-48.

14. Калинина-Шувалова, С.Ф. Очистка сточных вод предприятий молочной промышленности методом флотачии / С.Ф. Калинина-Шувалова // Новые идеи нового века: материаль международной научной конференции ФАД ТОГУ. - 2013. - T.2. - C. 304-308.

15. Калинина-Шувалова, С.Ф. Технологические схемь очистки жиросодержащих сточных вод / С.Ф. Калинина Шувалова, А.Ф. Криикая // Дальний Восток: проблемь развития архитектурно-строительного комплекса. 2013. - №1. - C. 313-319.

16. Сухарев, Ю.И. Ислледование прочесса электрофлотации жиров из сточных вод / Ю.И. Сухарев,
В.Р. Гофман, Е.В. Николаенко, Р.Р. Абдрашитов // Известия Челябинского научного иентра УРО РАН. - 1999. - №1. - C. 121-130.

17. Физико-химические методы очистки сточных вод предприятий молочной промышленности // Цельномолочная промышленность: обзорная информачия ЦНИИТЭИмясомолпром. - М., 1980. - 44 c.

18. Матов, Б.М. Электрохимическая стойкость анодных материалов в прочессе электрохимической очистки сточных вод / Б.М. Матов, Р.Я. Нападенский // Методы анализа очистки природных и сточных вод. - Кишинев, 1985. - C. 47-49.

19. Ильин, В.И. Электрофлотация. Пути развития / В.И. Ильин // Гальванотехника и обработка поверхности. 2014. - T.22, №4. - C. 49-52.

20. Ильин, В.И. Разработка технологических решений для очистки сточных вод от загрязнений органической природы / В.И. Ильин, В.А. Бродский, В.А. Колесников // Водоочистка. Водоподготовка. Водоснабжение. - 2015. №4. - C. 16-19.

21. Каратаев, О.P. Очистка сточных вод электрохимическими методами / О.Р. Каратаев, Шамсутдинова З.Р., Хафизов И.И. // Вестник технологического университета. - 2015. - T.18, №22. C. 21-23.

22. Лурье, Ю.Ю. Аналитическая химия промышленных сточных вод. - М.: «Химия», 1984. -448 c.

\section{References}

1. Sakash, G. V., Kolova, A. F., Pazenko, T. Ya. (2016). Wastewater treatment of milk processing plants, KrasGAU Bulletin, 8, 97-103.

2. Shevchenko, T.A., Shevchenko, A.A. (2015). Experimental study of intensification of the process of pressure flotation during wastewater treatment of a milk processing enterprise, Eastern European Journal of Advanced Technologies, $1 / 6$ (79), 4-12.

3. Andronov, V. A., Makarov, Ye. O., Danchenko, Yu. M., Obizhenko, T.M. (2020). Research of the regularities of forming and chemical composition of sewage water of a dairy processing company, Technogenic and ecological safety, 7, (1/2020), 13-21.

4. Makarov, Ye. O. (2020). Environmentally friendly highconcentration waste waters of milk processing plants, Sustainable Development - Status and Prospects: Proceedings of the II International Symposium SDEV'2020. Lviv, 235-236. 5. Konevych, M., Hud, V. (2011). Features of dairy wastewater, Proceedings of the $X V$ scientific conference of TNTU named after Ivan Pulyuy. Ternopil, 309.

6. Gerson de Freitas Silva Valente, Regina Celia Santos Mendonca, Jose Antonio Marques Pereira (2015). The efficiency of electrocoagulation using aluminum electrodes in treating wastewater from a dairy industry, Ciencia Rural, Santa Maria, 45, 9, 1713-1719.

7. Chezeau, B., Boudriche, L., Vial, C. and Boudjemaa, A. (2019). Treatment of dairy wastewater by electrocoagulation process: Advantages of combined iron/aluminum electrodes (published online 15.07.2019), Separation Science and Technology, 15.

8. Aitbara, A., Cherifi, M., Hazourli, S. and Leclerc, J.-P. (2016). Continuous treatment of industrial dairy effluent by electrocoagulation using aluminum electrodes, Desalination and Water Treatment, 57, 8, 3395-3404.

9. Benaissa, F., Kermet-Said, H. and Moulai-Mostera, N. (2016). Optimization and kinetic modeling of electrocoagulation treatment of dairy wastewater, Desalination and Water Treatment, 57, 13, 5988-5994. 
10. Varank, G., Sabuncu, M.E. (2015). Application of Central Composite Design approach for dairy wastewater treatment by electrocoagulation using iron and aluminum electrodes: modeling and optimization, Desalination and Water Treatment, $56,1,33-54$.

11. Ozornova, A.V. (2016). Investigation of the flotation process of dairy production wastewater treatment and development of a method for its intensification, Youth scientific and technical bulletin, 11, 20.

12. Ternovska, O. I., Kovtun, S. B., Kukushkin, A. I., Diakonov, V. I., Chebotariova, O. V., Fesenko, H. V. (2015) Treatment of industrial effluents of enterprises for processing livestock products from fat, Municipal economy of cities, 124 , 39-42.

13. Brodskii, V. A., Kisilenko, P. N., Kolesnikov, V. A., Gordienko, M. G. (2016). Electroflotation extraction of protein suspensions from aqueous solutions, Advances in chemistry and chemical technology, $X X X, 3,46-48$.

14. Kalinina-Shuvalova, S. F. (2013). Dairy industry wastewater treatment by flotation, New ideas of the new century: materials of the international scientific conference FAD TOGU, 2, 304-308.

15. Kalinina-Shuvalova, S. F., Kritskaia, A. F. (2013). Technological schemes for the treatment of greasy wastewater, Far East: problems of development of the architectural and construction complex, 1, 313-319.

16. Sukharev, Yu. I., Gofman, V. R., Nikolaienko, Ye. V., Abdrashitov, R. R. (1999). Investigation of the process of electroflotation of fats from wastewater, Bulletin of the Chelyabinsk Scientific Center of the Ural Branch of the Russian Academy of Sciences, 1, 121-130.

17. Physicochemical methods of wastewater treatment of dairy industry enterprises, Whole milk industry: overview information TSNIITEImyasomolprom, 44.
18. Matov, B. M., Napadenskii, R. Ya. (1985). Electrochemical stability of anode materials in the process of electrochemical wastewater treatment, Methods for the analysis of natural and waste water treatment, 47-49.

19. Iliin, V. I. (2014). Electroflotation. Development ways, Electroplating and surface treatment, 22, 4, 49-52.

20. Iliin, V. I., Brodskii, V. A., Kolesnikov, V. A. (2015). Development of technological solutions for wastewater treatment from organic pollution, Water treatment. Water treatment. Water supply, 4, 16-19.

21. Karataiev, O. R., Shamsutdinova, Z. R., Khafizov, I. I. (2015). Wastewater treatment by electrochemical methods, Technological University Bulletin, 18, 22, 21-23.

22. Lurie, Yu. Yu. (1984). Analytical chemistry of industrial wastewater, M.: "Chemistry", 448.

Рецензент: доктор технічних наук, професор, завідувач кафедри загальної хімії Ю.М. Данченко, Харківський національний університет будівництва та архітектури, Україна.

\section{Автор: МАКАРОВ Свген Олексійович}

науковий співробітник наукового відділу з проблем иивільного захисту та техногенно-екологічної безпеки науково-дослідного центту ичивільного захисту

Національний університет цивільного захисту України

E-mail-makarov1993@ukr.net

ORCID ID: https://orcid.org/0000-0003-0785-3041

\section{ELECTROFLOTATION TREATMENT OF DAIRY WASTEWATER: CHEMICAL-TECHNOLOGICAL} ASPECTS

National University of Civil Protection of Ukraine, Ukraine

Experimental researches are carried out and chemical-technological laws of reagent-electroflotation treatment of sewage of dairies are established. The wastewater of the milk processing enterprise of Sumy region was selected for the study. For reagent wastewater treatment, ferric chloride $\mathrm{FeCl}_{3}$ in the form of a $5 \%$ aqueous solution is selected. To accelerate the hydrolysis of the reagent as an alkaline additive was used calcium oxide (lime) CaO in dry form and sodium hydroxide $\mathrm{NaOH}$ in the form of $5 \%$ aqueous solution. To accelerate the formation of sediment (sludge) used flocculant nonionic polyacrylamide (PAA) in the form of $0.05 \%$ aqueous solution. The efficiency of treatment was studied by the following indicators of wastewater: hydrogen $\mathrm{pH}$, transparency and amount of ether-soluble substances. It is established that the process of extraction of ether-soluble substances largely depends on the pH of the medium and increases with increasing alkalinity of wastewater. The greatest influence of pH of the environment is observed at concentration of $\mathrm{FeCl}_{3}$ of $100-150 \mathrm{mg} / \mathrm{dm}^{3}$. When $\mathrm{FeCl}_{3}$ is added at a concentration of $200 \mathrm{mg}^{\prime} / \mathrm{dm}^{3}$, the purification effect does not depend on the $\mathrm{pH}$ of the medium. The most effective is the addition of ferric chloride and then lime. Initially, the addition of $\mathrm{FeCl}_{3}$ coagulates proteins and partially demulsifies the fat emulsion. After the introduction of lime into the water, hydrolysis and formation of iron hydroxide $\mathrm{Fe}(\mathrm{OH})_{3}$ occurs, on the surface of which contaminants are adsorbed. The greatest degree of purification from ether-soluble substances $87-88 \%$ is provided by addition of ferric chloride $\mathrm{FeCl}_{3}$ in concentration of 150-200mg / dm at $\mathrm{pH}$ of 9,5-10. It was found that when using lime to increase the pH of wastewater at a concentration of 500mg / $\mathrm{dm}^{3}$, there is a more efficient removal of ether-soluble substances and suspended solids (increased transparency), and less sediment is formed. Summarizing the obtained data, the optimal concentrations of reagents for pre-treatment of wastewater were selected - $\mathrm{FeCl}_{3}-$ $100 \mathrm{mg} / \mathrm{dm}^{3}, \mathrm{CaO}-500 \mathrm{mg} / \mathrm{dm}^{3}$ and wastewater $\mathrm{pH}-7.2$. It is shown that the reduction of the content of ethersoluble substances to $40 \mathrm{mg} / \mathrm{dm}^{3}$ (at the maximum permissible concentration for dairy wastewater $50 \mathrm{mg} / \mathrm{dm}^{3}$ ) is possible only at high processing time $\left(20-30\right.$ minutes) and density $\left(0.05 \mathrm{~A} / \mathrm{cm}^{2}\right)$ and voltage $(26 \mathrm{~V})$ electric current, which leads to high electricity consumption.

Keywords: wastewater, dairy, ether-soluble substances, electroflotation, reagent, degree of purification. 